\title{
Not Russia, but France and England shall decide about Poland: the diplomatic action of Roman Dmowski in 1916-1917
}

Zarys treści: W artykule podjęto próbę odtworzenia planów politycznych Romana Dmowskiego z lat 1916-1917 i skonfrontowania ich z planami wojenno-politycznymi Ententy, a szczególnie kierunkami polityki zagranicznej Francji i Wielkiej Brytanii. Wyeksponowano przede wszystkim dwie analizy polityczne Dmowskiego. Pierwsza z początku 1917 r., kiedy obawiał się on, iż może dojść do zakończenia wojny i zmniejszenia szans na odzyskanie przez Polskę niepodległości. Druga związana jest z jego instrukcją wysłaną przez Agencję Lozańską do Koła Międzypartyjnego w Warszawie w dniu 15 maja 1917 r.

Outline of content: The present article attempts to retrace Roman Dmowski's political plans from the years 1916-1917, and to confront them with the military and political plans of the Entente, especially the foreign policies of France and Great Britain. Particular focus was given to two of Dmowski's political analyses. The first one from early 1917, when he feared that the war might end too soon, thus reducing Poland's chances of regaining independence; the second one related to his instructions sent by the Polish Central Agency in Lausanne to the Inter-Party Political Circle in Warsaw on 15 May 1917.

Słowa kluczowe: Roman Dmowski, polska akcja dyplomatyczna 1916-1917, instrukcja Dmowskiego 15 maja 1917, sprawa polska w czasie I wojny światowej

Keywords: Roman Dmowski, Polish diplomatic action 1916-1917, Dmowski's instruction of 15 May 1917, Polish cause during World War I

In scholarly literature, the moment of Roman Dmowski's departure from Petrograd in the direction of the Entente Powers in November 1915 - a few months after the Central Powers had seized the territories of the Kingdom of Poland - as well as his statements from that period (as recorded by Stanisław Kozicki) have already been discussed many times. Dmowski allegedly asserted at the time that 
"Germany would undoubtedly be subdued, and the outcome of the war would be decided by the powers forming the Western coalition, rather than Russia. France and England would thus be determining the fate of Poland, and Russia would no longer have its say in this matter". ${ }^{1}$ All valid criticism of these predictions notwithstanding - or even the question whether they were indeed pronounced in 1915 - the analyses and actions performed by Dmowski and other Poles in 1916-1917, as well as the ever-changing military and political situation of the Great War, had a positive impact on Polish affairs in the final phase of the war and during the 1919 peace congress. Kozicki also noted that Dmowski's tactics after 1915 were partly founded on the principle of avoiding taunting Russia. He associated it with the memorandum handed by Dmowski to the Russian Ambassador to Paris, Aleksandr Petrovich Izvolsky, on 18 February 1916, a copy of which the leader of the National Democrats would then send to the governments of the Entente Powers. ${ }^{2}$ I will discuss this document later. In 1916, Dmowski still opted for negotiating with Russia, but by 1917, he had already excluded it from international competition. He was not alone in thinking so, though. Some Polish activists had been seeking assistance in France and Great Britain even before 1917, by attempting to convince the local politicians and opinion-forming elites to support their efforts towards the establishment of an independent Polish state, and to distance themselves from their Russian allies, if not abandon them. These voices were largely ignored, but in 1917 they acquired new power. Whatever the term used to emphasise the significance and role of the international events of the Great War taking place in 1917 - especially those in Russia, and their importance for Polish affairs - this year will undoubtedly remain an important one, if not ground-breaking. From the perspective of two political and military blocs, Russia, as a member of the Entente, was becoming in 1917 an increasingly troublesome element in this multinational jigsaw of powers. Heretofore, Russia had been an important and desirable ally of France, and of the United Kingdom as well, but its reliability then decreased steadily over the course of the year, rendering this country's war participation a threat. Ultimately, the signing of a ceasefire by the Bolsheviks with the Central Powers on 15 December 1917, and then of a peace treaty on 3 March 1918, effectively eliminated Russia from the Entente's war strategy. The hopes of Poles had also been boosted by President Woodrow Wilson's speech delivered in the U.S. Senate on 22 January 1917, and the statement therein: "there should be a united, independent, and autonomous Poland", as well as the fact that the United States joined the war against the Central Powers in April 1917. These changes in the balance of forces and alliances were of great importance for Polish affairs. Indeed, Poland's aspirations to freedom could have echoed in the

\footnotetext{
1 S. Kozicki, Pamiętnik 1876-1939, comp. by M. Mroczko, Słupsk, 2009, p. 297. This citation also appears in: R. Wapiński, Roman Dmowski, Lublin, 1988, p. 219.

2 Kozicki, Pamiętnik, pp. 298-299.
} 
offices of European decision-makers, and the Act of 5th November (1916) could have given them international importance, but it was not until 1917 that real chances of implementation of the Polish ambitions appeared.

We already dispose of significant, albeit not full knowledge, concerning Dmowski's diplomatic action in the Entente Powers and the memoranda submitted by him. ${ }^{3}$ What is missing is a comprehensive overview allowing the reconstruction and confrontation of Dmowski's intentions from that period with the military and political plans of the Entente, with particular regard to the foreign policies of France and Great Britain, especially those pertaining to Russia. The present paper will address said issues with emphasis on these lesser known fragments of Dmowski's political analyses. I will limit my considerations to the year 1916 and early 1917. I believe that this period was decisive for Dmowski's political reasoning and the actions undertaken by him in late 1917, especially after the Bolshevik Revolution in Russia.

\section{For the internationalisation of Polish affairs}

It seems that, in his efforts towards the internationalisation of the Polish cause, Dmowski wished to treat Russia as a partner for talks, at least until the February Revolution. ${ }^{4}$ However, his attitude in this matter evolved constantly in relation to his analysis of the international situation. Apparently, in 1916, he believed in the possibility of forcing this country to approve the voice of other Entente Powers regarding Polish affairs. Dmowski's actions were above all anti-German. $\mathrm{He}$

3 J. Pajewski, Wokót sprawy polskiej. Paryż, Lozanna, Londyn 1914-1918, Poznań, 1970; id., Odbudowa państwa polskiego 1914-1918, Warszawa, 1985; A. Micewski, Roman Dmowski, Warszawa, 1971; K. Kawalec, Roman Dmowski, Poznań, 2016 (2nd ed.); J. Niklewska, "Roman Dmowski w Londynie i w Paryżu w świetle jego archiwum z lat 1915-1919”, in: Myśl polityczna Romana Dmowskiego, ed. J. Engelgrad, Warszawa, 2009, pp. 45-66; M. Seyda, Polska na przełomie dziejów. Fakty i dokumenty, vol. 1, Poznań, 1927; M. Leczyk, Komitet Narodowy Polski a Ententa i Stany Zjednoczone 1917-1919, Warszawa, 1966; T. Schramm, "Dyplomacja francuska wobec kwestii autonomii Polski w 1916 r”., in: Ku Niepodległej. Ścieżki polskie i francuskie 1795-1918, ed. M. Willaume, Lublin, 2005, pp. 501-513; J. Zamoyski, Powrót na mapę. Polski Komitet Narodowy w Paryżu 1914-1919, Warszawa, 1991; P. Wandycz, "Dmowski’s Policy at the Paris Peace Conference: Success or Failure?”, in: The Reconstruction of Poland, 1914-1923, ed. P. Latawski, London, 1992, pp. 117-132; M. Gmurczyk-Wrońska, "Czy rok 1916 był ważny dla spraw polskich we Francji?”, Dzieje Najnowsze, 3 (2016), pp. 37-50; id., “Akt 5 listopada z francuskiej perspektywy”, in: Akt 5 listopada 1916 roku i jego konsekwencje dla Polski i Europy, eds. J. Kłaczkow, K. Kania, Z. Giżyński, Toruń, 2016, pp. 309-319.

${ }^{4}$ In historiography, this issue has always been interpreted variously; from pointing out Dmowski's clearly pro-Russian attitude to suggesting a purely instrumental treatment of Russia. The matter of Dmowski's attitude towards Russia, also in the context of differences in interpretation, is discussed by Jan Engelgrad, "Roman Dmowski wobec Rosji”, in: Myśl polityczna Romana Dmowskiego, ed. J. Engelgrad, Warszawa, 2009, pp. 67-100. 
correctly assumed that Germany's policy towards the Poles, following the seizure of the territories of the Kingdom of Poland by the Central Powers, resulted to a large extent from its political and military calculations aimed at taking the lead in Polish affairs and turning the Poles against Russia. ${ }^{5}$

It should be stressed, however, also in the context of Kozicki's records, that Dmowski's assumptions regarding international developments in the autumn of 1915 and later were largely based on his earlier analyses presented primarily in his work Germany, Russia and the Polish Cause, published in Warsaw in 1908, and then in Paris in 1909. ${ }^{6}$ Dmowski referred therein to the Polish political concepts from the late eighteenth and the nineteenth centuries, and pointed to the need for the existence of an independent Poland as an important factor for the European balance of power, which would primarily curb Germany's imperial aspirations, and constitute, to some extent, an obstacle to a possible Russian-German agreement. Dmowski believed that either an independent Poland would arise, or Europe would be "ruled from Berlin". ' In his opinion, the awareness of the German threat should become a "source of interest" in Polish affairs for the European decision-makers, given that "Germany's dangerously growing power and the south-eastern direction of its expansion would make Poland the foremost barrier to its victorious march. This new role of our nation ought to make the Polish cause one of the most important European matters in the nearest future". ${ }^{8}$ Dmowski also expressed harsh criticism of Russia's imperial policies that affected Polish interests. In 1908, Dmowski hoped that a "new" Russia, allied with West European countries, could support the national interests of Poles, just as the other members of the Triple Alliance should. He believed that, in order to achieve this, Poland's cause had to be internationalised first, and only then would Poland's independence become possible. Thus, even before the outbreak of the war, Dmowski already considered Polish affairs as one with the policies of the Entente Powers (including Russia), and perceived them as allies in Poland's struggle for freedom.

The year 1916 was a prolific one for Dmowski's political writings, which were a development of his previous analyses. In the autumn of 1915, he argued that, in the event of the seizure of Polish lands by the Central Powers, the Polish affairs would become part of the political deliberations between the superpowers, leading consequently to their internationalisation. According to Dmowski's strategy, this was an essential step towards further efforts aimed at the restoration of Poland's

${ }^{5}$ R. Dmowski, Polityka polska i odbudowa państwa [reprint], Warszawa, 2008, p. 232.

6 The Paris version was published with the title La question polonaise, translated by Wacław Gasztowtt, and prefaced by Anatole de Leroy-Beaulieu (publ. by A. Colin).

7 R. Dmowski, Niemcy, Rosja i kwestia polska, comp. by N. Tomczyk, Wrocław, 2013 (7th ed.), p. 151. Dmowski's political ideas in the context of this publication are discussed by M. Kornat, "Niemcy, Rosja i kwestia polska. Refleksje historyka sto lat później", Przegląd Polityczny, 88 (2008), pp. 34-49.

8 Dmowski, Niemcy, Rosja i kwestia polska, p. 142. 
independence. In January 1916, when journeying in Italy, Dmowski met with Cardinal Secretary of State Pietro Gasparri, Secretary of the Congregation for Extraordinary Ecclesiastical Affairs Monsignor Eugenio Pacelli, and, most importantly, Pope Benedict XV. He also exchanged opinions with officials of the French Embassy in Rome. The French diplomats later submitted a report from this meeting to their head office at Quai d'Orsay in Paris under the significant title La question polonaise. As they recall, Dmowski invoked the threat of Germany's eventual success in establishing a new political entity out of a part of the Polish lands. In order to counteract this, he proposed an intervention of Western powers with the Russian authorities, with the aim of persuading them to support the idea of an independent Polish state. The French side found this idea unrealistic, of course, but they did not rule out Russia's positive reaction to the Polish cause. ${ }^{9}$ In February 1916, Dmowski took part in the congress of representatives of pro-Allied groups in Lausanne, which affirmed the necessity of undertaking action within the Entente states - including, of course, in Russia - in favour of an "independent Polish state" ${ }^{10}$ Dmowski followed this course of action by addressing the Memorandum Concerning the Recognition of Poland's Independence to the Russian government by intermediary of Aleksandr Izvolsky, the Russian Ambassador to Paris. ${ }^{11}$ In Dmowski's 1926 publication Polish Politics and the Rebuilding of the State, the memorandum appears with this title. However, when his collaborator, the lawyer Marian Seyda, quoted a fragment in his 1927 book Poland at the turn of time. Facts and documents, the document is referred to as Roman Dmowski's Memorandum. One can therefore presume that the document's title did not include the word "independence", even if Dmowski used this notion in his talks with the French officials. It should nonetheless be emphasised, as is stressed by Janusz Pajewski, that Dmowski attached great importance to this idea. ${ }^{12}$ Indeed, he insisted that the document handed to Izvolsky marked "the beginning of our action towards the internationalisation of the Polish cause" and towards "the inclusion of Poland's independence in the war agenda". ${ }^{13}$ In his memorandum, Dmowski performs an analysis of international relations with a view, in particular, to Germany's threat to peace in Europe, as well as the German aspirations to eliminate Russia from international politics, and to extend their influence over areas controlled by Russia in the past, including Polish territories. The text therefore stresses the necessity

\footnotetext{
9 Archive of the French Ministry of Foreign Affairs (hereinafter: AMAEF), series Guerre 1914-1919, Guerre Russie, file 714, fol. 133-144; ibid. in: file 717, fol. 246-251. This document is also discussed by Schramm, Dyplomacja francuska, p. 502.

10 Seyda, Polska na przełomie dziejów, pp. 301-302. The congress was attended, besides Dmowski, by Marian Seyda, Erazm Piltz, Konstanty Plater, Witold Czartoryski, Maciej Loreta, and Maurycy Zamoyski.

11 The contents of the Letter in: Dmowski, Polityka polska, pp. 433-440.

12 Pajewski, Odbudowa państwa polskiego, p. 174.

13 Dmowski, Polityka polska, pp. 185-186.
} 
of persuading Russia to take the Polish aspirations seriously. It also includes a denunciation of the tsarist state for its idleness in relation to the Polish issue. In the event of Germany overtaking initiative in relation to Poland, Dmowski urged Russia to carry out pro-Polish measures. ${ }^{14}$ Especially that, while he was staying in France - i.e. Russia's ally, whom he also sought to involve in the political game that he and his political bloc played with Russia - he let himself express both words of criticism and flattery. Dmowski presumably attempted to initiate relations with French decision-makers in the spring of 1916, but it proved extremely problematic. It should be noted, however, that practically from the beginning of 1916, the Russian authorities had repeatedly attempted to convince British and French politicians that Polish affairs are exclusively in their hands and should not become the subject of international debates. Ambassador Izvolsky's influence did make an impact not just at Quai d'Orsay, where he even tried to threaten France with the potential deterioration of Russian-French relations in the case the latter would support the aspirations of the Polish nation, but also in the French press. ${ }^{15}$ It was not difficult, as the French did recognise their Eastern ally as a natural partner, and they actually considered Polish affairs to be Russia's internal issues. The French political and diplomatic spheres were therefore, for obvious reasons, very cautious in this matter. In a memorandum to the Prime Minister and Foreign Minister Aristide Briand of April 1916, Maurice Paléologue, French Ambassador to Petrograd, wrote as follows: "Poland's independence is unacceptable not just to Russia; it also constitutes a threat for France [...] An autonomous Poland under the Romanovs: such a solution seems the most desirable from the French perspective". ${ }^{16}$ However, further study of the letter between Briand and Paléologue written in 1916 may arouse the impression that the French authorities were constantly surveying the Russian side with regard to Polish affairs, or even indirectly attempting to "force" the Russians to take more open action towards the Poles. Yet still, this did not mean support for Poland's independence, but solely to the idea of its autonomy within the Russian Empire. The withdrawal of Russians from the territories of the Polish Kingdom in 1915 caused an impact on French political and military analyses. There was of course little concern that Russia would withdraw from war, but the expansion of German and Austrian influence over such a large portion of Polish territories, and the subsequent appropriation of the Polish cause previously reserved to Russians, raised questions among French decision-makers about their country's eastern policies, and about the political and military condition of their ally. It should nonetheless be emphasised once again that the Russians did not allow the French to ask too inquisitive questions about

\footnotetext{
${ }^{14}$ Ibid., p. 439.

15 I. Spustek, "Sprawa polska w polityce Rosji w roku 1916”, in: Dzieje Najnowsze Polski. Materiały i studia $z$ okresu 1914-1939, vol. 2, Warszawa, 1959, p. 19, http://rcin.org.pl/dlibra/docmetadata?id=44634\&from=publication (accessed: 5 November 2017).

16 Quoted by Schramm, Dyplomacja francuska, p. 504.
} 
Poland. It was the Russian Foreign Minister Sergei Sazonov who reminded Paléologue of the price that the Second Empire had paid one century earlier for supporting the Poles - thus causing, in his opinion, Russian-Prussian rapprochement - and of the battles of Königgrätz and Sedan. The Russian minister did not shy away either from criticising the Poles for their constant pursuit of independence and appeals to foreign countries. ${ }^{17}$ In relation to these words, Paléologue advised Briand on 19 April 1916 that France remain prudent and cautious in Polish affairs, as the alliance with Russia should be maintained "at any price". 18 On the next day, Briand instructed his ambassador that the Polish matter should not be brought up in talks with Russians. ${ }^{19}$ On 26 April 1916, a memorandum was issued by the French ministry, stating that France would not engage in official talks with Russia regarding Poland. ${ }^{20}$ Also in April, a conversation took place at the Quai d'Orsay between Erazm Piltz - journalist, politician, and founder of the Central Polish Agency in Lausanne - and Pierre de Margerie - Director of the Department for Political Affairs - during which it was stated that Petrograd would never allow the internationalisation of Polish affairs. ${ }^{21}$ We do not know whether Piltz discussed this visit with Dmowski, and whether Dmowski had any detailed information about France's standpoint. It appears that he only possessed general knowledge, and yet it still allowed him to assess quite precisely the chances of obtaining France's support for the Polish cause as low. He thus placed greater hopes in Great Britain. Besides, Dmowski had already visited this country in the autumn of 1915, and returned there many times. He managed to establish many valuable contacts among the local elites. ${ }^{22}$ Even though Great Britain was also bound by alliance with Russia as an Entente Power, Russia played a much less important role in British policies than in French ones. Marian Seyda noted that "during this period, [Great Britain] offered Dmowski a greater freedom of action", as this country was not as constrained by Russia as France was. ${ }^{23}$ This was all true, which means Dmowski and his camp were actually correct in their interpretation of the Entente's balance of forces at that time. Dmowski was indeed extremely logical in his assessment of international relations. One could even say that this caused his plans to be too idealistic, as they resulted from the conviction that there was room for Polish affairs in the fairly rational British policies. This is why Dmowski met in March 1916 with Lord Robert Cecil, Under-Secretary of State for Foreign Affairs, and sent him the same memorandum that he had handed earlier

17 AMAEF, Guerre 1914-1918, Russie, file 715, fol. 4, telegram by Paléologue to Briand, 18 April 1916. Also in Schramm, Dyplomacja francuska, p. 503.

18 AMAEF, Guerre 1914-1918, Russie, file 715, fol. 30, telegram by Paléologue to Briand, 19 April 1916.

19 Ibid., fol. 31-32, telegram by Briand to Paléologue, 20 April 1920.

${ }^{20}$ Ibid., fol. 61; Note of dep. Europe, 26 April 1916.

${ }^{21}$ Ibid., 715, fols. 45-46, April 1916, note from conversation between de Margerie and Piltz.

22 More: Niklewska, Roman Dmowski w Londynie, pp. 46-50; Kawalec, Roman Dmowski, p. 251.

${ }^{23}$ Seyda, Polska na przełomie dziejów, pp. 297-298. 
to Izvolsky. ${ }^{24}$ Tadeusz Piszczkowski's research proved that, following consultations with Dmowski, the British did put the Polish matter into consideration, but, seeing it as too sensitive, they refrained from intervening with Russia. ${ }^{25}$ On average, the British decision-makers were even more critical of Poland's independence. In his memorandum to the government of 4 October 1916, entitled The Peace Settlement in Europe, Foreign Minister Lord James Arthur Balfour asserted that the establishment of a Polish state between Germany and Russia was not in Great Britain's interest. Balfour believed that this could lead to German-Russian rapprochement in the future. He considered the idea of Poland's autonomy within the Russian Empire to be the only viable scenario, and promoted this idea in the memorandum of 26 March $1917 .{ }^{26}$ It is very likely that Dmowski was not aware of the existence of these documents. His encounter with Balfour took place in March 1917. This subject will be discussed later. In 1916, Dmowski was seeking a more favourable moment for the internationalisation of Polish affairs. Such an opportunity appeared in the autumn of 1916, when the Central Powers proclaimed the Act of 5th November. Even though Dmowski would criticise the agreement between the two emperors, he admitted that "itcontributed to educating European politicians about the international importance of the Polish matter. It provided a powerful stimulus for them to address this subject more seriously". ${ }^{27}$ Dmowski was only partly correct; the Polish issue had been internationalised to some extent, but from the point of view of France, Italy, and Great Britain, it remained Russia's internal affair. Despite some satisfaction, Dmowski was concerned by the pro-German efforts of Russian Prime Minister and Foreign Minister Boris V. Stürmer, aimed at achieving a separatist peace with Germany. If this were to happen, Dmowski's entire plan - which assumed the Allies' involvement in Poland's cause - would fold, as the Polish affairs would presumably be decided once again by Russia and Germany.

\section{The Entente's perspective: France}

Even though after the proclamation of the Act of 5th November, the heads of governments of the Entente Powers would still give Russia a free hand in resolving the Polish issue, there was general agreement that Russia did not succeed in this matter. Russia remained an important ally in the Entente camp, but the fact that

${ }^{24}$ More: T. Piszczkowski, Anglia a Polska 1914-1939, London, 1975, pp. 8-10; Niklewska, Roman Dmowski w Londynie, pp. 49-50.

25 Ibid., p. 11.

${ }^{26}$ J. Ciechanowski, "Polityka brytyjska wobec Polski w okresie konferencji pokojowej w Wersalu", in: Wielka Brytania a Polska. Od Wersalu do Jałty, Pułtusk, 2008, p. 37; M. Kornat, "Co dał narodowi polskiemu Akt 5 listopada? Perspektywa międzynarodowa”, in: Akt 5 listopada 1916 roku, pp. 225-226; Kawalec, Roman Dmowski, p. 257.

27 Dmowski, Polityka polska, p. 242. 
some territories of the Kingdom of Poland had been seized by the Central Powers, who then took over the initiative in Polish affairs, had an impact on the critical evaluation of Russia's political and military potential. In addition, it was feared that, following the Act of 5th November, the planned conscription of Poles to the German army would result in the strengthening of the military power of the Central Powers, leading to the transfer of some of their troops to the western front.

The wartime goals of the Allied Powers in the first period of the conflict were fairly general, rather limited to deliberations and verbal declarations. The first documents setting out these objectives in a more exhaustive manner date from late 1916. They were undoubtedly connected with the military and political situation on the eastern front, perhaps with the Act of 5th November, and also with the rumours about the possibility of Russia concluding a separatist peace with Germany. The French political elites, headed by Aristide Briand, decided to propose new objectives to Russia, envisaging the expansion of its influence over the Polish territories under German rule. ${ }^{28}$ It should be noted, however, that unofficial talks on this issue had been taking place since 1915. On 4 and 6 November 1916, Secretary General at the French Ministry of Foreign Affairs Jules Cambon addressed two instructions to his brother Paul, who served as Ambassador in London, which assumed a maximalist plan of "crushing Germany". ${ }^{29}$ The document of 4th November postulated the inclusion of "Prussian Poland" into "Russian Poland", connected with Russia as an autonomous region. It should be added that the instruction of 6th November, as emphasised by French researcher Georges-Henri Soutou, had probably been conceived in consultation with Pierre de Margerie or his deputy Philippe Berthelot. It envisaged larger territorial concessions by Germany, or, more broadly, the break-up of Germany and Austria-Hungary, and raised the issue of creating a stable foundation for lasting peace in a Europe based on independent nations. Independence for Poland, however, was out of the question. Although it was mentioned that the future Polish territories should include the areas seized by Prussia, Austria and Russia at the end of the eighteenth century, as well as access to the sea, but this entity was to function as an autonomous part of the Russian Empire. ${ }^{30}$ The French introduced slight modifications on 12 January 1917, but no changes were made in relation to the Polish territories. These plans also became a foundation for negotiations between the Entente's members. ${ }^{31}$ As a result of both these measures, and of the above-mentioned talks with Russians held since 1915 in relation to the delimitation of the borders of France and Russia following victory in the war, was the famous decision of the French Council of Ministers of 5 March 1917, followed by an exchange of letters between the French and Russian

\footnotetext{
28 G.-H. Soutou, La grande illusion. Quand la France perdait la paix 1914-1920, Paris, 2015, p. 113.

29 Ibid., pp. 115-121.

${ }^{30}$ Ibid., pp. 116-117.

31 Ibid., pp. 121-125, 130.
} 
governments on 11 March 1917, concerning the consent of the French authorities to the unrestrained delimitation by Russia of its post-war western borders. ${ }^{32}$ This fact was a discredit to Prime Minister and Minister of Foreign Affairs Aristide Briand in the eyes of not just the Poles, but the French opposition as well. Besides, Tsar Nicholas II eventually abdicated on 16 March, and the diplomatic correspondence between France and Russia concerning this event fell into the hands of the Bolsheviks. They took advantage of this opportunity for propaganda goals by publishing these documents in Izvestia in November 1917.

The French historiography dedicated to the subject of the Great War describes end-1916 and the year 1917 as a time of clash between war exhaustion and important changes, which ultimately resulted in the Entente's victory. In 1917, France struggled with numerous political and military problems; vast strikes of workers and rebellions of soldiers only complemented this picture. Faced with the activism of workers' movements and the upsurge of the revolutionary doctrine, this state of war fatigue combined with economic issues (therefore alimentary ones too) could prove extremely dangerous for the whole of Europe. ${ }^{33}$ The speech delivered on 22 January 1917 by Woodrow Wilson, followed by the entry of the United Stated into war in April, made an important impact in France. The French could have been reluctant towards President Wilson's slogans and concepts, but Europe desperately needed American soldiers. And it was all the more important for the French, who were concerned by the news they received in early June 1917 about the atmosphere of discouragement and expectation for peace among the Russian troops. Gen. Edmond Buat, a member of the French General Staff, noted in his journal on 5 June 1917: "the situation is precarious, and unless we find a solution, we are heading towards disaster". ${ }^{34}$ French military and diplomatic envoys would also express shock in late 1917 at the sight of the "disintegration" of the 10-million strong Russian army (2.5 million being active fighters). ${ }^{35}$ Consequently, both the decision of the American authorities and events in Russia, despite not being connected in any way, effectively led to an increase in diplomatic activity of the warring countries and a breakthrough in the war.

In spite of the overthrow of the tsar in March 1917 and the takeover of power by the Russian Provisional Government, the French hoped to continue cooperation

32 More: Leczyk, Komitet Narodowy Polski, pp. 91-117; Pajewski, Wokół sprawy polskiej, pp. 142144; W. Śladkowski, Opinia publiczna we Francji wobec sprawy polskiej w latach 1914-1918, Wrocław, 1976, p. 183; J.-B. Duroselle, Wielka wojna Francuzów 1914-1918, transl. by A. Ciastek, Warszawa, 2006, p. 253.

33 P. Renouvin, Histoire des relations internationalles, 1914-1929, vol. 7, Paris, 1957, pp. 60-62, 90-93.

34 Journal du général Edmond Buat 1914-1923, comp. by F. Guelton, Paris, 2015, entries dated 1 and 5 June 1917, pp. 399-400.

35 J.-B. Duroselle, Wielka wojna Francuzów 1914-1918, p. 198. 
as allies. ${ }^{36}$ This was due for the most part to the importance of Russia within the Entente, but also to the desire of the French to protect their capital. Tsarist Russia had indeed taken out huge loans from France, and in consequence, both during the period in question and years later, economic issues remained among the most important in the French-Russian relations. It should be noted, however, that immediately after the Bolshevik revolution, the French displayed a certain reticence concerning the new authorities. Cooperation with the new government was expected to continue nonetheless, in spite of certain disagreements in this matter. For the French, it was crucial that Russia remain in the Entente camp, even if ruled by Bolsheviks. It is true what A. Hogenhuis-Seliverstoff writes that France faced a dilemma in late 1917: should they seek to maintain the already weak alliance with Russia (even under Bolshevik rule?), or focus on preserving their influence in the region. The author draws attention to the issue of great controversy and confusion among French political, military and economic elites regarding Russia. During the Provisional Government period in June 1917, France appointed a new ambassador to Petrograd (following the recall of Maurice Paléologue). Joseph Noulens arrived in mid-July. ${ }^{37}$ Before leaving for Russia, he held meetings with leading representatives of the French commercial sector with ties to the Russian market. ${ }^{38}$ His mission was primarily to supervise the situation in Russia, to watch over French capital, and to actively prevent Russia from leaving the Entente.

The beginnings of Noulens's mission aroused optimism. Alas, when the coming to power of the Bolsheviks resulted in the nationalisation of French capital, and in the initiation of negotiations with the Central Powers in December 1917, it became clear that France and the Entente altogether were losing Russia. It was undoubtedly more painful for France than for other Entente Powers, but it was only in the autumn of 1917 that France had begun to modify its eastern policies, drawing up plans to replace Russia as ally by seeking cooperation with other nations, including Poland. ${ }^{39}$ On the other hand, the idea of supporting Poles

36 A. Hogenhuis-Seliverstoff, Les relations franco-sovietiques 1917-1924, Paris, 1981, pp. 18-20.

37 Ibid., pp. 23-28.

38 M. Mourin, Les relations franco-sovietiques 1917-1967, Paris, 1967, p. 40.

39 Discussions regarding the fate of oppressed European nations were taking place in France during the war. But it was not until the end of 1917, and especially 1918, that Paris officially began to support such nations, including the Poles, in their struggle for independence. French scholars, however, emphasise that these issues were very controversial. Even until the peace conference, the French Government and the French Parliament would experience tensions between conservatives, i.e. those who supported at least to some extent the domination of superpowers (=empires) in Central and Eastern Europe, and the left-wing (socialists, left-wing liberals), who were proponents of offering support to oppressed nations in this part of Europe. The younger generation of diplomats at the Quai d'Orsay - Philippe Berthelot and Pierre de Margerie although involved in previous cabinets, began to develop, since autumn 1917, the theory of four pillars in France's foreign policy. After the alliance with Russia had collapsed, in order to curb the imperial tendencies of Germany and protect itself against a possible new conflict on Germany's 
in their struggle for freedom, and perceiving them as a possible ally, remained non-existent in British policies at that time. Although, after the declaration of the Russian Provisional Government, which included the notion of a separate Polish state, the British politicians would no longer reiterate the concept of an autonomous Poland within the Russian Empire, it was not until January 1918 that they officially began to discuss Poland's independence.

\section{Poland's perspective: focus on the United Kingdom}

One key event for the aspirations of the Polish nation was President Wilson's speech of 22 January 1917, where he stated that "there should be a united, independent, and autonomous Poland". However, the news incoming from Russia aroused both optimism and anxiety; the questions about the outcome of the "Russian turmoil" were becoming urgent. For this reason, in spite of a certain dose of optimism, Roman Dmowski referred to the spring of 1917 as "one of the most dangerous [...] moments in the entire war" with regard to the Polish cause..$^{40}$ Dmowski feared the war could end in early 1917, resulting in "white peace" (as it was called in France), which would constitute an unsatisfactory outcome for Polish affairs. Several years later, Dmowski wrote that it was not until April 1917, i.e. the United States' entry into the war, that new perspectives for the Polish nation opened up, and only then did the threat of an early end to the war disappear. He considered Wilson's speech extremely important in general, but pointed out the unfavourable implications of the fragment concerning Poland. The U.S. president's aspirations for "peace without annexations or reparations", given the pacifist tendencies in Europe (especially in France) and prevailing war fatigue, were simply dangerous. Although the Act of 5 th November had a positive impact on the internationalisation of Polish affairs, the Entente had not issued a joint statement supporting the pro-independence efforts of Poles. If a peace conference had taken place in spring 1917, and Russia had participated in it, it is likely that Polish affairs would remain in its hands. Moreover, after the Provisional Government took power in Russia, Dmowski feared its stance on the Polish issue, which could, of course, further strengthen Russia's view on the Polish issue within the Entente. In the spring of 1917, Dmowski adopted the tactic of pressuring politicians from the Entente as intensely as possible towards issuing some kind of joint statement regarding this matter. These plans included the idea of establishing an organisation representing Polish interests in relation to the Entente. It should be added, however, that Dmowski's actions at

part, France was expected to seek alliances with Poland, Czechoslovakia, Yugoslavia and Romania. In 1917, however, these plans were not taken seriously, and Clemenceau, having distanced himself from this idea, decided to focus on the United States. It was not until 1919 that Berthelot's and de Margerie's concept was taken into consideration again.

40 Dmowski, Polityka polska, p. 271. 
that time had a twofold character: on the one hand, he acknowledged the threat of the war ending too soon, he criticised the Provisional Government in Russia, and warned Western politicians about it; but on the other, he would send fairly optimistic signals to Poland confirming that the Entente would offer its support, and, at the same time, he mobilised his supporters to act collectively. Dmowski and his entourage were aware of the efforts of the "activist" camp (supporters of cooperation with the Central Powers) in the Kingdom of Poland; the institutions created as a consequence of the Act of 5th November, such as the Provisional Council of State, were in opposition to his camp and the entire pro-Allied concept. This is evidenced by his "letter to the home country" from the turn of January and February 1917, in which he advocated the creation of an organisation supervising "Polish foreign policies", ${ }^{41}$ and by the memorandum of his collaborator Marian Seyda handed in February 1917 to several diplomatic representatives of Allied countries, where he called for the entire coalition to issue a statement asserting its intention to "rebuild a united and independent Poland", which would constitute a reference to the speech made by President Wilson on 22 January $1917 .{ }^{42}$

In the spring of 1917, Dmowski's diplomatic activity gained substantial momentum, and his memorial action was truly impressive. This subject has already been widely discussed in literature, therefore, for the purposes of the present article, focus will be placed on chosen aspects. ${ }^{43}$ In March 1917, before the Provisional Government's declaration, Dmowski travelled to Great Britain. As during previous visits, he met with local leading politicians. On $21 \mathrm{March}$, during a conversation with Secretary of State Arthur Balfour, he urged the latter that the Allied governments issue a joint declaration with the Russian Provisional Government regarding Poland's independence. He also asked the British diplomat to intervene in this matter with Russia. Balfour did do so, but it seems that he rather intended to survey the situation, than to actually encourage Russia to take that step. Dmowski also handed Balfour an aide-mémoire (Pro memoria), in which he justified the necessity of issuing such a joint declaration by the Entente. Given that he perceived the potential measures of the Russian authorities as a declaration of the Russian government alone, he demanded, in the same tone as Seyda's memorandum, that all "governments of Allied Powers declare that Poland will be united and rebuilt as an independent state". ${ }^{44}$ At the same time, he expected these countries to

${ }^{41}$ Seyda, Polska na przełomie dziejów, pp. 595-596. Letter to the home country penned by Roman Dmowski, sent by the congress of political activists in Western Europe, which took place in Lausanne between 26 January and 2 February 1917, pp. 595-597. The letter was analysed by Leczyk, Komitet Narodowy Polski, pp. 66-70; and Pajewski, Odbudowa państwa, p. 175.

${ }^{42}$ Seyda, Polska na przełomie dziejów, pp. 612-614.

${ }^{43}$ These issues were discussed by, among others: Pajewski, Wokół sprawy polskiej; id., Odbudowa państwa; Leczyk, Komitet Narodowy Polski; Kawalec, Roman Dmowski, pp. 268-271.

44 Dmowski, Polityka polska, p. 443, Full text translated from English, aide-mémoire handed to Secretary of State Balfour by R. Dmowski after conversation on 25 March 1917 in London regarding the recognition of Poland's independence by Allied Powers and Russia, pp. 442-444. 
compel the current Russian authorities to join that declaration. The Entente Powers (including Russia with its Provisional Government, which still belonged to the coalition) would therefore collectively support the idea of Poland's independence, to be then confirmed at an international conference. ${ }^{45}$ These facts are, of course, familiar to researchers; what I want to stress here is that Dmowski pursued his earlier efforts from 1916 aimed at snatching Polish affairs from Russia's control and internationalising them, leading to the inclusion of Poland's freedom into the objectives of the ongoing war. ${ }^{46}$

What is noteworthy is that, in March and July 1917, Dmowski's efforts were focused on Great Britain. It should be stressed that, following the proclamation made by the Russian Provisional Government, the French authorities, and the British and Italian ones alike, issued separate statements in this matter. These declarations were disappointingly vague, filled with slogans about support for the Russian efforts in the name of the principles of freedom. ${ }^{47}$ Besides, as is already known, in addition to the aforementioned memorandum of 25 March, Dmowski also handed Balfour the Memorandum Concerning the Territories of the Polish State in late March, and a document in the form of a note addressed to the English government entitled Russia's Stance on the Polish Issue in the Ongoing War. ${ }^{48} \mathrm{In}$ the latter, he quoted successive Russian declarations regarding the Polish nation, including that of Minister of Justice Aleksandr Kerensky. However, he abstained from commenting on it. A few months later, in July 1917, in his famous text entitled Central and Eastern European Issues, he speculated that Russia would disappear from the "international scene" for "many generations". ${ }^{49}$ On this note, I would like to draw greater attention to a document that is also known to researchers, yet I believe it receives too little interest and is analysed too vaguely. I am referring here to Dmowski's 12-page instruction sent by the Lausanne Agency to the Inter-Party Political Circle in Warsaw on 15 May 1917. The Polish version of this document is kept at the National Archive in Kraków. ${ }^{50}$ The document is also available in French; such a copy is available at the Diplomatic Archives in Paris. ${ }^{51}$

${ }^{45}$ For more on this subject, see: Piszczkowski, Anglia a Polska, pp. 16-21; Wapiński, Roman Dmowski, pp. 229-232.

${ }^{46}$ More: M. Gmurczyk-Wrońska, “Czy rok 1916 był istotny dla spraw polskich w polityce Francji”, Dzieje Najnowsze, 3 (2016), pp. 37-50.

47 These declarations are quoted by Seyda, Polska na przełomie dziejów, pp. 621-622.

48 These documents in: Dmowski, Polityka polska, pp. 445-449.

49 Ibid., pp. 474-479.

50 Dmowski's instruction sent by the Lausanne Agency to the Inter-Party Political Circle in Warsaw, National Archive in Kraków (hereinafter: ANK), NKN fonds, microfilm 105, fols. 338-349. The document was analysed by: Pajewski, Odbudowa państwa, p. 179; Wapiński, Roman Dmowski, p. 242.

51 AMAEF, Europe 1918-1929, Pologne, file 66, the document containing information regarding the translated text, i.e. Dmowski's instruction dated 15 May 1917, bears the date of 11 October 1918 and is listed as "confidential", fols. 9-19. This means that it was not until October 1918 
Judging by the title, this document, although not signed by Dmowski, was most probably dictated by him and written down by someone from the Lausanne Agency. It constitutes, to a large extent, a supplementation of Dmowski's "letter to the home country" and another encouragement of his followers to support the concept of an organisation representing Polish affairs in Western Europe. In this sense, it is actually an instruction for its recipients from the "passivist" block, i.e. the Inter-Party Political Circle in Warsaw, which operated since October 1915 and regrouped such factions as the Real Politics Party (Stronnictwo Polityki Realnej), the National Democratic Party (Stronnictwo Demokratyczno-Narodowe), the Polish Progressive Party (Polska Partia Postępowa), the Association for Economic Independence (Związek Niezależności Gospodarczej), the National Unity Party (Zjednoczenie Narodowe), and the Christian Democratic Party (Stronnictwo Chrześcijańsko-Demokratyczne). ${ }^{52}$ This document offers an analysis of the international situation in the spring of 1917, of the position of Polish affairs in the policies of the superpowers, and of the forecasts regarding the nation's future, as well as, most importantly, suggestions regarding the identity of the future principal ally of independent Poland. That ally was expected to be Great Britain. Dmowski was convinced back then that during the future peace conference, Great Britain and the United States would jointly play a leading role in the establishment of a free Polish state. He assumed that France and Italy would play a secondary role, while Russia's would tertiary, or even quaternary. The United Kingdom, in his opinion, assumed a dominant position among the Allied Powers, based on its superior military and economic potential.

It appears that Dmowski was strongly impressed by the attitudes and competences of British decision-makers, or intensely tried to convince his supporters in Warsaw in favour of the pro-British option, pointing out that "London constitutes the centre of gravity for Polish affairs". ${ }^{53}$ Having taking Russia's decreasing significance on the international scene as granted, he believed that London would rather direct its eastern policies at Japan and China, and seek protection from Germany by supporting Poland and establishing an alliance with Warsaw in the future. Dmowski believed in Great Britain's help ever since the proclamation of the Act of 5th November, when London began to fear the far-reaching consequences of the dominance of Central Powers in Central Europe, given the decreasing potential of Russia. The breakthrough moment in London's approach to Polish affairs was,

that the French, or anyone from the Polish community, translated this text. The French context of this writing, as well as the position and assessment by the French of the Polish National Committee in 1918, would constitute enough material for a separate article.

52 J. Molenda, Piłsudczycy a Narodowi Demokraci 1908-1918, Warszawa, 1980, p. 226; Seyda, Polska na przełomie dziejów, pp. 581-583. Until August 1916, the Inter-Party Political Circle also comprised the Polish Progressive Union (Polskie Zjednoczenie Postępowe), the National Labour Party (Stronnictwo Pracy Narodowej), and the National Party (Stronnictwo Narodowe).

53 ANK, NKN fonds, fol. 342. 
according to Dmowski, the overthrow of the tsar and the assumption of power by the Provisional Government. Dmowski attached great importance to the attitude of officials in the Foreign Office, and believed that Balfour was "committed to the Polish cause", ${ }^{54}$ he only expressed scepticism towards the Lloyd George's stance. It should be stressed that Dmowski's collaborator Marian Seyda shared his point of view, and was just as involved in diplomatic action in favour of Poland in Great Britain. Dmowski hoped that Italy would follow Great Britain in the process of supporting Polish affairs; he also noticed slight positive changes in the attitude of the Holy See.

Regarding France, Dmowski stated as follows: "It would seem that we should share a stronger bond with France than with England, but they are strongly involved financially in Russia and look up to this country, expecting it to be a warrant of dominance over Germany in the future" ${ }^{55} \mathrm{He}$ did acknowledge certain pro-Polish sentiments among the French politicians and press, especially in the Parliament, but he remained sceptical with regard to the chances of obtaining actual support from the Third Republic. He also mentioned the director of the political department at the French Ministry of Foreign Affairs, Pierre de Margerie, who expressed friendliness towards the Polish nation; however, he stressed that, following the declaration made by the Provisional Government, even de Margerie had informed Erazm Piltz: "everything has been done, everything has been accomplished, here is nothing more that can be done" ${ }^{56}$ Dmowski pointed out Piltz's strong ties with the French authorities at Quai d'Orsay, but admitted not sharing his opinions. He described them as subjective, a long way from a true analysis of the international situation. Piltz's position in the French diplomatic and political spheres, as well as the tensions between him and Dmowski, are arguably among the most interesting aspects of Polish diplomatic tactics in 1917. A lot of information on this subject is already available by virtue of the research carried out by Agnieszka Kidzińska ${ }^{57}$ and Andrzej Szczepaniak. ${ }^{58}$ Piltz's opinions and actions were in direct opposition to those of Dmowski. It is well known that the relations of these two gentlemen were characterised by constant antagonism, if not an open conflict. However, they were stuck with each other, and eventually did cooperate. Piltz had been representing the pro-Russian option much longer than Dmowski. Contrary to Dmowski's attempts to pressure the entire Entente (including Russia) into taking a common stand with regard to Poland's independence, Piltz consistently believed for a long time that the Polish cause could and should be discussed and negotiated with Russia. His

54 Ibid., fol. 343.

55 Ibid., fol. 345.

56 Ibid., fol. 345.

57 A. Kidzińska, "Stosunki Erazma Piltza z francuskim MSZ podczas I wojny światowej”, in: Ku Niepodległej. Ścieżki polskie i francuskie 1795-1918, ed. M. Willaume, Lublin, 2005.

58 A. Szczepaniak, Od autonomii do niepodległości. Działalność polityczna Erazma Piltza w latach 1914-1929, Opole, 2015. 
faith in the Russian Liberals and Democrats, and his vision of a reformed Russia that would give hope for good relations with Poles, was in clear contradiction to Dmowski's speculations regarding Russia's weakening and decreasing importance. It should be mentioned that, after the tsar was overthrown and the Provisional Government took over, Piltz wrote on 28 March 1917 a rather particular letter to the then Foreign Minister of France, Stephen Pichon. Therein, he criticised Dmowski for pressuring France into supporting the idea of Poland's independence. Piltz believed that acting too fast could harm the Polish interests. He speculated that the Entente could stand more firmly in defence of Polish affairs only after the end of the war, at the peace conference. Andrzej Szczepaniak also notes that Dmowski, after submitting his aide-mémoire to Balfour, asked Piltz to transmit it to the authorities at the Quai d'Orsay. Piltz, as an opponent to exerting pressure on France and England, refused. ${ }^{59}$ He advised more restraint. Since mid-1917, Piltz was involved, alongside Wacław Gąsiorowski and Adam Mokiejewski, in the process of establishment of a Polish army in France. To this end, he published the text Mémoire sur la création de l'armée polonaise en France (Memorandum on the Creation of the Polish Army in France), where he referred to France as the future ally of Poland. French President Raymond Poincaré issued a decree on the formation of the Polish army in France on 4 June 1917.

Although Dmowski eventually welcomed the creation of the Polish army, he maintained his pro-British stance until the summer, if not autumn of 1917. His endeavours culminated in the publication of the widely discussed memorandum Central and Eastern European Issues from July 1917 delivered to Balfour.

Dmowski's assessment of the British policies proved wrong. However, he had been attentively monitoring the French political climate and, as soon as France lost its most valuable ally, he switched to the pro-French option, paving the way for close cooperation with this country. The existence, since 15 August 1917, of the Polish National Committee, and the evolutions in French foreign policies following the Bolshevik Revolution in Russia, eventually allowed him to undertake action towards the integration of Poland's independence into the Entente's wartime objectives. This goal was ultimately achieved at the conference in Versailles on 3 June 1919.

Dmowski, when leaving for Western Europe in autumn 1915, hoped to obtain support for Polish affairs from France and Great Britain. In 1916, he attempted to establish contacts in France, but in view of the scarce interest displayed by the Third Republic - allied at the time with Russia - with regard to Polish affairs, he placed focus on Great Britain. Janusz Pajewski correctly assessed that Dmowski had overestimated the importance of Polish affairs in the policies of the Entente. ${ }^{60}$ However, the Polish politician knew when to withdraw from erroneous assumptions.

\footnotetext{
59 Ibid., s. 322.

${ }^{60}$ Pajewski, Odbudowa państwa polskiego, pp. 244-245.
} 
In 1917, Polish affairs gained international importance, and it was only a matter of time when the Polish state would emerge; the only question being what shape it would take. By the end of the year, Poland became a key matter, as the Western powers, France in particular, were actively revising their wartime objectives. In view of the broken, or at least severely weakened alliance with Russia, France began to modify the vectors of their eastern policies. Dmowski and his camp managed to take advantage of this opportunity.

\section{Bibliography}

\section{Archival material}

Archives du Ministère des Affaires Étrangères Français, Série Guerre 1914-1919, Guerre Russie, file 714 .

Archiwum Narodowe w Krakowie, zespół NKN, microfilm 105.

\section{Literature}

Ciechanowski J., "Polityka brytyjska wobec Polski w okresie konferencji pokojowej w Wersalu", in: Wielka Brytania a Polska. Od Wersalu do Jałty, Pułtusk, 2008.

Dmowski R., Niemcy, Rosja i kwestia polska, comp. by N. Tomczyk, 7th ed., Wrocław, 2013.

Dmowski R., Polityka polska i odbudowa państwa, Warszawa, 2008 [reprint].

Duroselle J.-B., Wielka wojna Francuzów 1914-1918, transl. by A. Ciastek, Warszawa, 2006.

Engelgrad J., "Roman Dmowski wobec Rosji”, in: Myśl polityczna Romana Dmowskiego, ed. J. Engelgrad, Warszawa, 2009, pp. 67-100.

Gmurczyk-Wrońska M., "Akt 5 listopada z francuskiej perspektywy", in: Akt 5 listopada 1916 roku i jego konsekwencje dla Polski i Europy, ed. J. Kłaczkow, K. Kania, Z. Giżyński, Toruń, 2016, pp. 309-319.

Gmurczyk-Wrońska M., "Czy rok 1916 był istotny dla spraw polskich w polityce Francji”, Dzieje Najnowsze, no. 3 (2016), pp. 37-50.

Hogenhuis-Seliverstoff A., Les relations franco-sovietiques 1917-1924, Paris, 1981.

Journal du général Edmond Buat 1914-1923, comp. by F. Guelton, Paris, 2015.

Kawalec K., Roman Dmowski, 2nd ed., Poznań, 2016.

Kidzińska A., "Stosunki Erazma Piltza z francuskim MSZ podczas I wojny światowej”, in: Ku Niepodległej. Ścieżki polskie i francuskie 1795-1918, ed. M. Willaume, Lublin, 2005.

Kornat M., "Co dał narodowi polskiemu Akt 5 listopada? Perspektywa międzynarodowa", in: Akt 5 listopada 1916 roku i jego konsekwencje dla Polski i Europy, ed. J. Kłaczkow, K. Kania, Z. Giżyński, Toruń, 2016.

Kornat M., "Niemcy, Rosja i kwestia polska. Refleksje historyka sto lat później”, Przegląd Polityczny, no. 88 (2008), pp. 34-49.

Kozicki S., Pamiętnik 1876-1939, comp. by M. Mroczko, Słupsk, 2009.

Leczyk M., Komitet Narodowy Polski a Ententa i Stany Zjednoczone 1917-1919, Warszawa, 1966.

Micewski A., Roman Dmowski, Warszawa, 1971.

Molenda J., Piłsudczycy a Narodowi Demokraci 1908-1918, Warszawa, 1980, p. 226.

Mourin M., Les relations franco-sovietiques 1917-1967, Paris, 1967. 
Niklewska J., "Roman Dmowski w Londynie i w Paryżu w świetle jego archiwum z lat 19151919”, in: Myśl polityczna Romana Dmowskiego, ed. J. Engelgrad, Warszawa, 2009.

Pajewski J., Odbudowa państwa polskiego 1914-1918, Warszawa, 1985.

Pajewski J., Wokół sprawy polskiej. Paryż, Lozanna, Londyn 1914-1918, Poznań, 1970.

Piszczkowski T., Anglia a Polska 1914-1939, London, 1975.

Renouvin P., Histoire des relations internationalles, 1914-1929, vol. VII, Paris, 1957.

Schramm T., "Dyplomacja francuska wobec kwestii autonomii Polski w 1916 r", in: Ku Niepodległej. Ścieżki polskie i francuskie 1795-1918, ed. M. Willaume, Lublin, 2005.

Seyda M., Polska na przełomie dziejów. Fakty i dokumenty, vol. 1, Poznań, 1927.

Soutou G.-H., La grande illusion. Quand la France perdait la paix 1914-1920, Paris, 2015.

Spustek I., “Sprawa polska w polityce Rosji w roku 1916”, in: Dzieje Najnowsze Polski. Materiały i studia $z$ okresu 1914-1939, vol. 2, Warszawa, 1959.

Szczepaniak A., Od autonomii do niepodległości. Działalność polityczna Erazma Piltza w latach 1914-1929, Opole, 2015.

Śladkowski W., Opinia publiczna we Francji wobec sprawy polskiej w latach 1914-1918, Wrocław, 1976.

Wandycz P., "Dmowski's Policy at the Paris Peace Conference: Success or Failure?", in: The Reconstruction of Poland, 1914-1923, ed. P. Latawski, London, 1992.

Wapiński R., Roman Dmowski, Lublin, 1988.

Zamoyski J., Powrót na mapę. Polski Komitet Narodowy w Paryżu 1914-1919, Warszawa, 1991.

Dr hab. Malgorzata Gmurczyk-Wrońska, professor at the Institute of History of the Polish Academy of Sciences in Warsaw. Her main fields of research are: international relations and diplomacy in the 20th century, Polish society during World War I. She has published, among others: Polska - niepotrzebny aliant Francji? [Poland: France's superfluous ally?], Warszawa, 2003; Stanisław Patek $w$ dyplomacji i polityce (1914-1939) [Stanisław Patek in diplomacy and politics (1914-39)], Warszawa, 2013 (mwronska5@wp.pl). 